\title{
PROPOSAL
}

\section{AUDIT SISTEM INFORMASI RS UMUM ABDUL MOELOEK}

Disusun untuk Memenuhi Tugas Mata Kuliah Audit Sistem Informasi

Dosen : Ochi Marshella Febriani, S.KOM,. M.T.I

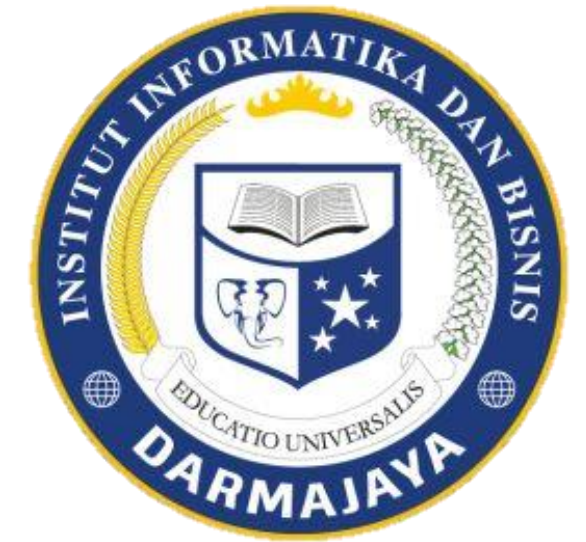

Disusun Oleh :

Dian Arista

1611050100

P03

Fakultas Ilmu Komputer

Jurusan Sistem Informasi

Institut Informatika \& Bisnis Darmajaya

Bandar Lampung

2019 


\section{RUMAH SAKIT UMUM DAERAH DR. H. ABDUL MOELOEK PROVINSI LAMPUNG \\ BAB I \\ PENDAHULUAN}

\subsection{Sejarah RumahSakit}

Rumah Sakit Umum Daerah Dr. H. Abdul Moeloek pada mulanya merupakan Rumah Sakit Ondering Pemerintahan hindia belanda yang didirikan pada tahun 1914 untuk buruh perkebunan Saat itu bangunan Rumah Sakit masih semi permanen dengan kapasitas seratus tempatidur. Setelah Indonesia merdeka RSUD Dr. H. Abdul Moeloek menjadi RSU Pemerintah Sumatera Selatan tahun 1950-1964 untuk selanjutnya menjadi RSU Tanjung Karang, Teluk Betung saat Lampung menjadi provinsi sendiri. Setelah menjadi RSUD Provinsi Lampung pada tahun 1965 sesuai SK Gubernur Lampung 07 agustus 1984 Rumah Sakit ini berubah nama menjadi RSUD Dr. H. Abdul Moeloek hingga saat ini. Tahun 1993 sesuai SK Menkes RI Nomor :1163/Menkes/SK/XII/1993 RSUD Dr. H. Abdul Moeloek dikategorikan menjadi RSUD Kelas B Non Pendidikan. Berdasarkan Peraturan daerah Provinsi Lampung No. 8 tahun 1995 pada tanggal 2CVESD7 februari 1995, RSUD 63 Dr. H. Abdul Moeloek Provinsi Daerah Tingkat I Lampung disahkan oleh Menteri Dlam Negeri dengan surat keputusan No. 139 tahun 1995. Kemudian RSUD Dr. H. Abdul Moeloek ditetapkan menjadi Rumah Sakit Unit Swadana Daerah berdasarkan Peraturan Daerah Provinsi Lampung No. 12 tahun 2000. Selanjutnya seiring berjalannya waktuperkembangan terakhir menjadi RSUDTipeBpendidikantepatnyatanggal23juli2008danRSUD-PPK-BLUD dengan status penuh melalui Pergub Lampung nomor : 605 G/V/HK 2009, pada tanggal 24 september 2009. RSUD Dr. H. Abdul Moeloek merupakan Rumah Sakit Rujukan tertinggi di provinsi Lampung. Dalam rangka upaya peningkatan pelayanan kesehatan yang bermutu, efektif, efisien dan optimal, pada 
tahun 2000 dilakukan relokasi kelas perawatan dan jumlah tempat tidur yang sebelumnya 555

tempat tidur dikurangi menjadi 400. Namun tahun 2005 kapasitas ditambah menjadi 460 tempat tidur mengingat jumlah pasien yang terusmeningkat.

STRUKTUR ORGANISASI RS UMUM ABDUL MOELOEK

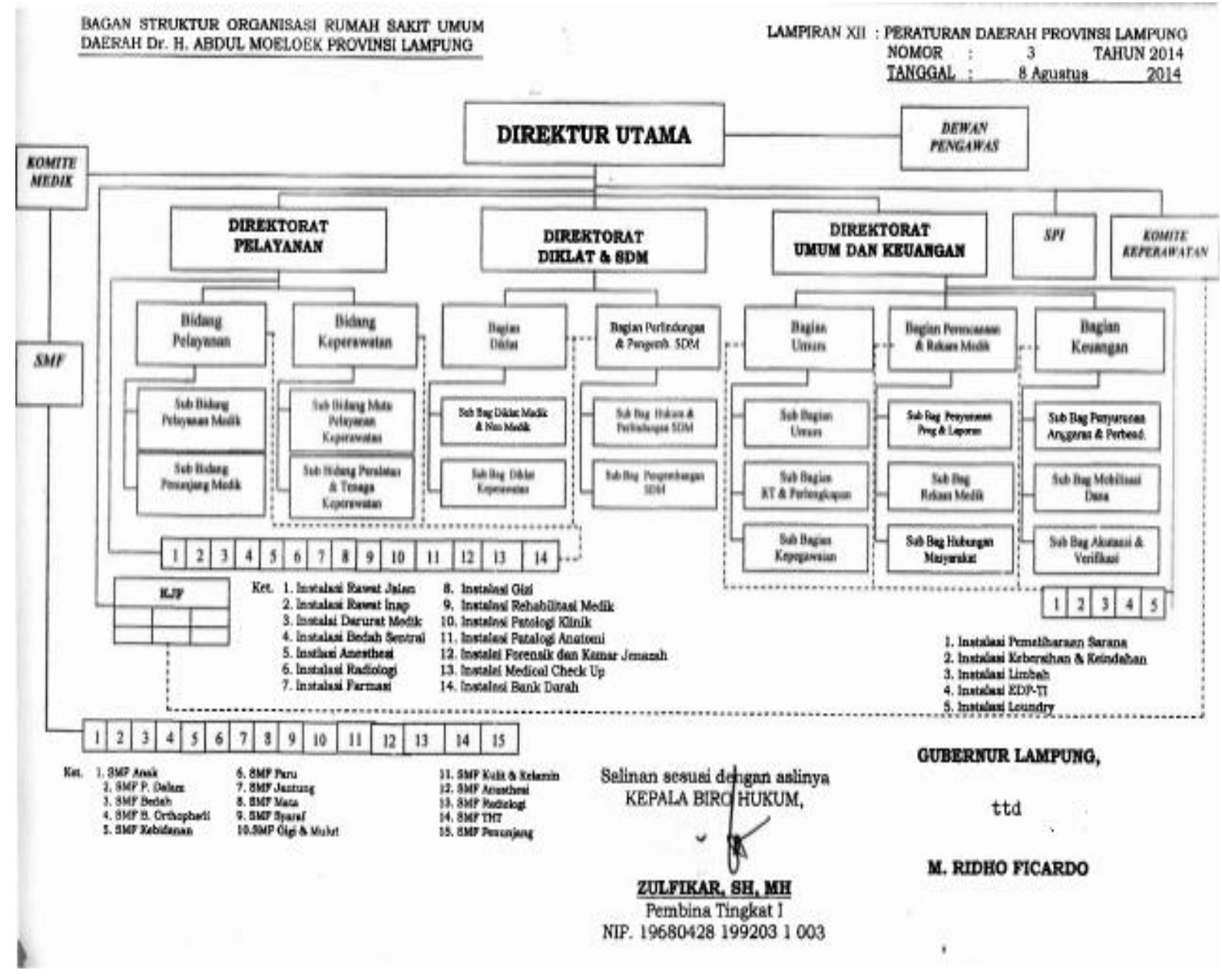


STRUKTUR ORGANISASI

RUANG KENANGA

RSUD DR .H.ABDUL MOELOEK PROVINSI LAMPUNG

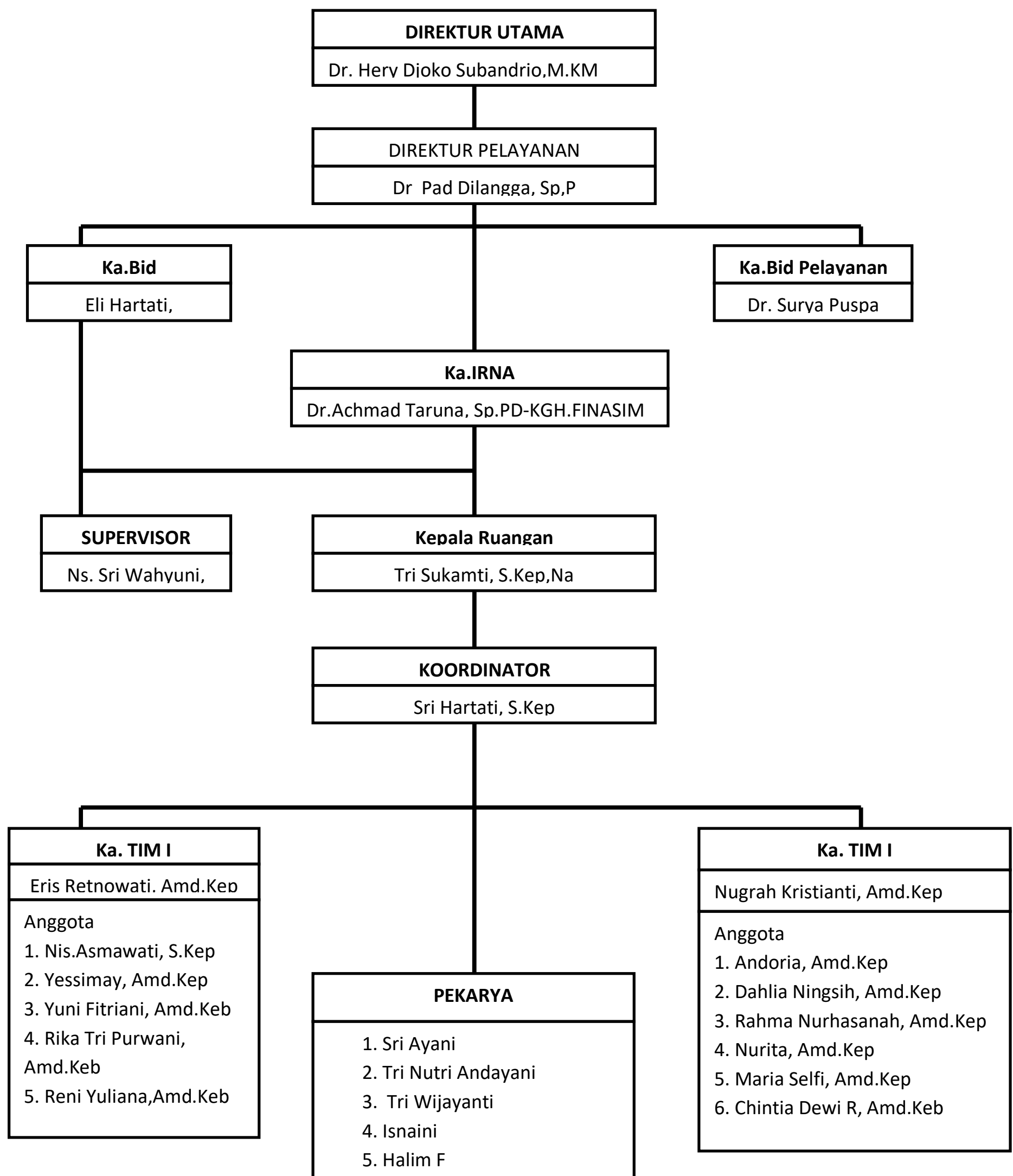




\section{Bergerak dibidang}

Rumah Sakit rujukan tertinggi diprovinsi Lampung, RSUD Dr. H. Abdul Moeloek suatu rumah sakit umum daerah lampung yang bergerak dibidang kesehatan

\subsection{Pengaruh terhadap lingkungan sekitar}

Makin disadari bahwa kegiatan rumah sakit (RS) yang sangat kompleks tidak saja memberikan dampak positif bagi masyarakat sekitarnya, tapi juga mungkin dampak negative Dampak positif berupa produk pelayanan kesehatan yang baik terhadap pasien dan memberikan keuntungan retribusi bagi pemerintah dan lembaga pelayanan itu sendiri, rumah sakit juga dapat menimbulkan dampak negatif berupa pengaruh buruk kepada manusia, seperti sampah dan limbah rumah sakit yang dapat menyebabkan pencemaran lingkungan, sumber penularan penyakit dan menghambat proses penyembuhan serta pemulihan penderita.Limbah berupa virus dan kuman yang berasal dan Laboratorium Virologi dan Mikrobiologi dapat membahayakan kesehatan para petugas, pasien maupun masyarakat. Sampai saat ini belum ada alat penangkalnya sehingga sulit dideteksi. Selain itu, limbah cair, limbah padat dan limbah gas yang dihasilkan RS dapat pula menjadi media penyebaran gangguan atau penyakit, berupa pencemaran udara, pencemaran air, tanah, pencemaran makanan dan minuman. Pengelolaan limbah RS yang tidak baik akan memicu resiko terjadinya kecelakaan kerja dan penularan penyakit dari pasien ke pekerja, dari pasien ke pasien, dari pekerja ke pasien, maupun dari dan kepada masyarakat pengunjung RS. Tentu saja RS sebagai institusi yang sosio-ekonomis karena tugasnya memberikan pelayanan kesehatan kepada masyarakat, tidak terlepas dari tanggung jawab pengelolaan limbah yang dihasilkan.

\subsection{Produk yang dihasilkan}

Rumah Sakit adalah untuk menghasilkan produk, jasa atau pelayanan kesehatan yang benarbenar menyentuh kebutuhan dan harapan pasien dari berbagai aspek, yang menyangkut medis dan non medis, jenis pelayanan, prosedur pelayanan, harga dan informasi yang dibutuhkan.

\subsection{Penghargaan yang pernah diraih}

Rumah Sakit Umum Daerah Abdul Moeloek (RSUDAM) Lampung meraih penghargaan Unit Pelayanan Publik Kategori Baik dengan catatan 2018 dari Kementrian Pendayagunaan Aparatur Negara dan Reformasi Birokrasi (PAN-RB), di Rafflesia Grand Ballroom, Balai Kartini, Jakarta Selatan, Selasa (27/11). Penghargaan diberikan Menteri PAN-RB Syafruddin kepada Gubernur Lampung Muhammad Ridho Ficardo. Penghargaan itu disampaikan pada acara penyampaian hasil evaluasi dan apresiasi pelayanan publik 2018.

Menurut Mentri PAN-RB, pemberian pelayanan itu sebagai upaya menjadikan pelayanan publik lebih supportif dan mengutamakan kepuasan pengguna layanan (customer driven government). Idealnya, kata Syafruddin, pemerintah harus berjalan seiring dengan kehendak publik. 


\subsection{Misi dan Tujuan RumahSakit}

Sebagai Rumah Sakit rujukan tertinggi diprovinsi Lampung, RSUD Dr. H. Abdul Moeloek memiliki Visimenjadi Rumah Sakit unggul dalam pelayanan, pendidikan, dan pelayanan. RSUD

Dr. H. Abdul Moeloek memiliki Misi utama yaitu :

a. Menyelenggarakan pelayanan kesehatan yang bermutu, profesional, dengan mengutamakan keselamatan pasien.

b. Menyelenggarakan proses pendidikan dan penelitian yang mengarah pada pembangunan ilmu dan teknologi di bidang kedokteran dan perumah sakitan yang menunjang pelayanan kesehatan prima berdasarkan standar nasional dan internasional.

Motto RSUD Dr. H. Abdul Moeloek yaitu ASRI, merupakan singkatan dari

\section{Aktif, Segera, Ramah dan Inovatif.}

\section{Tugas pokok danfungsinya}

c. TugasPokok

Melaksanakan upaya kesehatan secara berdayaguna dan berhasilguna dengan mengutamakan upaya penyembuhan dan pemulihan yang dilaksanakan secara serasi dan terpadu dengan upaya peningkatan dan pencegahan serta melaksanakan upayarujukan.

Fungsi

a. Melaksanakan upaya pelayananmedis.

b. Malaksanakan upaya rehabilitasimedis.

c. Melaksanakan pencegahan akibat penyakit dan peningkatan serta pemulihankesehatan.

d. Melaksanakan upayaperawatan.

e. Melaksanakan upaya pendidikan danlatihan.

f. Melaksanakan sistemrujukan.

g. Sebagai tempatpenelitian. 


\section{B. JenisPelayanan}

Dalam memberikan pelayanan kesehatan kepada masyarakat, RSUD Dr. H. Abdul Moeloek melaksanakan berbagai macam jenis pelayanan kesehatan sesuai fungsi, kapasitas, serta kewajibannya dalam meningkatkan derajat kesehatan masyarakat diantaranya:

1. Klinik VCT

2. Klinik Menopouse

15. Spesialis patologi anatomi

3. Klinik wanita korban kekerasan

16. Spesialis patologi klinik

17. Spesialis onkologi

4. Klinik bedah

18. Spesialis urologi

5. Spesialis obstetri \& ginekologi

19. Spesialis radiologi

6. Spesialis kesehatan anak

20. Spesialis kardiologi

7. Spesialis penyakit dalam

21. Spesialis penyakit paru

22. Spesialis bedah plastik

8. Spesialis kesehatan mata dan tht

23. General check up (GCU)

9. Spesialis gigi dan mulut/orthodenti

24. Visum dan forensik

10. Spesialis saraf

11. Spesialis orthopedi

12. Spesialis bedah saraf

13. Spesialis rehabilitasi medik

14. Spesialis anastesi 


\section{Latar Belakang}

Dalam upaya menilai kinerja puskesmas natar, maka dilakukan sebuah

Kegiatan audit untuk mengidentifikasi kesenjangan kinerja yang menjadi masukan untuk melakukan perbaikan dan penyempurnaan baik $\mathrm{p}$ [ada sistem pelayanan maupun sistem manajemen.

\section{D . Tujuan Audit}

a. mendapatkan data dan informasi factual dan significan

b. dasar pengambilan keputusan

c. pengendalian menejemen, perbaikan atau perubahan

\section{E. Ruang lingkup}

Unit yang di gunakan adalah bagian UKP (Unit Kesehatan Perorangan) 


\section{BAB II}

\section{TINJAUAN PUSTAKA}

\subsection{Definisi Audit}

Menurut Mulyadi “ audit adalah suatu sitem sistematik untuk memperoleh dan mengavaluasi bukti

Secara objektif mengenai pernyataan pernyataan mengenai kegiatan dan kejadian ekonomi, dengan tujuan untuk menetapka tingkat kesesuaian antara pernyataan pernyataan tersebut dengan kriteria yang telah di tetapkan serta, pemakaian hasil hasilnya ang berkepentingan

COBIT adalah sebuah standar pengelolaan teknologi informasi atau IT governance yang dikeluarka oleh ISACA, konsep dari kerangka kerja COBIT adalah bahwa kontrol terhadap sistem informasi dapat dilakukan dengan cara menentukan informasi informasi yang dibutuhkan untuk mendukung objektif bisnis dan informasi yang di kontrol adalah informasi tantang semua sumber daya yang terkait dalam proses proses sistem informasi.

\subsection{Tujuan Audit}

$\sim$ mengurangi resiko

$\sim$ menyelaraskan IT dengan sasaran bisnis

memperkuat IT sebagai unit bisnis utama

oprasi bisnis lebih transparan

$\sim$ meningkatkan efektifitas dan efesiensi.

\subsection{Definisi COBIT}

COBIT adalah sebuah standar pengelolaan teknologi informasi atau IT governance yang dikeluarka oleh ISACA, konsep dari kerangka kerja COBIT adalah bahwa kontrol terhadap sistem informasi dapat dilakukan dengan cara menentukan informasi informasi yang dibutuhkan untuk mendukung objektif bisnis dan informasi yang di kontrol adalah informasi tantang semua sumber daya yang terkait dalam proses proses sistem informasi.

IT Governance menggunakan COBIT ITGI didirikan pada 1998 untuk meningkatkan pemikiran dan standar internasional dalam mengarahkan dan mengontrol TI sebuah perusahaan. Tata kelola TI yang efektif dapat membantu perusahaan dalam memastikan bahwa TI mendukung tujuan bisnis, mengoptimalkan investasi dalam TI, dan dengan tepat mengatur risiko dan peluang yang terkait dengan TI. 
Salah satu yang dikeluarkan oleh ITGI adalah COBIT yang merupakan set of best practices (framework) bagi pengelolaan teknologi informasi (IT management). CobIT dapat dipakai sebagai alat yang komperhensif untuk menciptakan IT Governance pada suatu perusahaan. COBIT mempertemukan dan menjembatani kebutuhan manajemen dari celah atau gap antara risiko bisnis, kebutuhan kontrol dan masalah-masalah teknis TI, serta menyediakan referensi best business practices yang mencakup keseluruhan TI dan kaitannya dengan proses bisnis perusahaan dan memaparkannya dalam struktur aktivitas-aktivitas logis yang dapat dikelola serta di kendalikan secara efektif.

COBIT mendukung manajemen dalam mengoptimumkan investasi TI nya melalui ukuran-ukuran dan pengukuran yang akan memberikan sinyal Universitas Sumatera Utara bahaya bila suatu kesalahan atau risiko akan atau sedang terjadi. Manajemen perusahaan harus memastikan bahwa sistem kendali internal perusahaan bekerja dengan baik, artinya dapat mendukung proses bisnis perusahaan yang secara jelas menggambarkan bagaimana setiap aktivitas kontrol individual memenuhi tuntutan dan kebutuhan informasi serta efeknya terhadap sumber daya TI perusahaan. Sumber daya TI merupakan suatu elemen yang sangat disoroti COBIT, termasuk pemenuhan kebutuhan bisnis terhadap: efektivitas, efisiensi, kerahasiaan, keterpaduan, ketersediaan, kepatuhan pada kebijakan/aturan dan keandalan informasi (effectiveness, efficiency, confidentiality, integrity, availability, compliance, dan reliability).

Alasan mengenalkan COBIT

1). Isu interprise governance

2). Investasi IT optimal

3). Menegndalikan sumber daya IT, mengelola sumber daya IT dengan baik

4). Dapat di gabungkan dengan metode audit lainya

5). Dapat di modifikasi sesuai dengan keadaan

6). Meningkatkan audit terintegrasi

\section{Manfaat}

Bagi manajemen : menyeimbangkan resiko dan pengendalian investasi

Bagi user : mendapatkan jaminan keamanan dan kontrol layanan IT 
Bagi auditor : membantu pihan menejemen tentang pentingnya kontrol terhadap sumber daya IT

\subsection{Alasan mengenalkan COBIT}

1). Isu interprise governance

2). Investasi IT optimal

3). Menegndalikan sumber daya IT, mengelola sumber daya IT dengan baik

4). Dapat di gabungkan dengan metode audit lainya

5). Dapat di modifikasi sesuai dengan keadaan

6). Meningkatkan audit terintegrasi

Manfaat

Bagi manajemen: menyeimbangkan resiko dan pengendalian investasi

Bagi user : Mendapatkan jaminan keamanan dan kontrol layanan IT

Bagi auditor :membantu pihan menejemen tentang pentingnya kontrol terhadap sumber daya IT.

Tabel 2.2.

Domain \& High Controls COBIT

\begin{tabular}{|c|l|l|}
\hline NO & \multicolumn{1}{|c|}{ COBIT Domain } & \multicolumn{1}{c|}{ High Level Objectives } \\
\hline 1 & Planing and Organisation & 1. Difine a strategic IT Plan and Direction \\
& 2. Difine the information architecture \\
& & 3. Determine technological direction \\
& 4. Difine IT processes, organization and relationship \\
& 5. Manage the IT investment \\
& 6. Communicate management aim and direction \\
& 7. Manage IT human resources \\
& 8. Manage Quality \\
& 9. Assess and managed it risk \\
& 10. Manage projects \\
\hline
\end{tabular}




\begin{tabular}{|c|c|c|}
\hline 2 & $\begin{array}{l}\text { Acquisition and } \\
\text { Implementation }\end{array}$ & $\begin{array}{l}\text { 1. Identify automated solutions } \\
\text { 2. Acquire and maintain application software } \\
\text { 3. Acquire and maintain technology infrastructure } \\
\text { 4. Enable operation and use } \\
\text { 5. Procure IT recources } \\
\text { 6. Manage Changes } \\
\text { 7. Install and accredit solutions and changes }\end{array}$ \\
\hline 3 & Deliver and Support & $\begin{array}{l}\text { 1. Define and manage service levels } \\
\text { 2. Managed thrid-party services } \\
\text { 3. Manage performance and capacity } \\
\text { 4. Ensure continuous service } \\
\text { 5. Ensure systems security } \\
\text { 6. Identify and allocate costs } \\
\text { 7. Educate and train users } \\
\text { 8. Manage services desk and incidents } \\
\text { 9. Manage the configuration } \\
\text { 10. Manage problems } \\
\text { 11. Manage data } \\
\text { 12. Manage the physycal environment } \\
\text { 13. Manage operations }\end{array}$ \\
\hline 4 & Monitor and Evaluate & $\begin{array}{l}\text { 1. Monitor and evaluate IT processes } \\
\text { 2. Monitor and evaluate internal control } \\
\text { 3. Ensure regulatory compliance } \\
\text { 4. Provide IT Governance }\end{array}$ \\
\hline
\end{tabular}

The COBIT Framework mengukur kinerja TI dengan hal-hal berikut ini :

* Maturity Models

Untuk memetakan status maturity proses-proses TI (dalam skala 0-5), yaitu 0 - Non

Existent , 1 - Initial , 2 - Repetable , 3 - Defined, 4 - Managed dan 5- Optimized.

* Critical Success Factors (CSFs)

Arahan implementasi bagi manajemen agar dapat melakukan kontrol atas proses TI.

* Key Goal Indicators (KGIs) 
Kinerja proses-proses TI sehubungan dengan business requirements.

* Key Perfomance Indicators (KPIs)

Kinerja proses-proses TI sehubungan dengan process goals. 


\section{BAB III}

\section{METODELOGI PENELITIAN}

\subsection{Tahapan audit sistem informasi}

1. Planing

2. Pemeriksaan lapangan

3. Pelaporan

4. Tindak lanjut
4.1 investasi dan penyelidikan awal
4.2 pengujian atas control
4.3 pengujian ats transaksi
4.4 pengujian atas keseimbangan atau hasil keseluruhan
4.5 penyelesaian audit

\subsection{Pengumpulan data}

\section{Observas}

Pengertian observasi dapat dirumuskan sebagai berikut :

"Observasi ialah metode atau cara-cara yang menganalisis dan mengadakan pencatatan secara sistematis mengenai tingkah laku dengan melihat atau mengamati individu atau kelompok secara langsung"

cara atau metode tersebut dapat juga dikatakan dengan menggunakan teknik dan alat-alat khusus seperti blangko-blangko, checklist, atau daftar isian yang telah dipersiapkan sebelumnya. Dengan demikian, secara garis besar teknik observasi dapat dibagi menjadi dua, yaitu :

1).Structured or controlled observation (observasi yang direncanakan, terkontrol)

2).Unstructure or informal observation (observasi informasi atau tidak terencanakan lebih dahulu).

Pada structured observation, biasanya mengamat menggunakan blangko-blangko daftar isian yang tersusun, dan didalamnya telah tercantum aspek-aspek ataupun gejala-gejala apa saja yang perlu diperhatikan pada waktu pengamatan itu dilakukan.

Adapun pada unstructurred observation, pada umumnya pengamat belum atau tidak mengetahui sebelumnya apa yang sebenarnya harus dicatat dalam pengamatan itu. Aspekaspek atau peristiwanya tidak terduga sebelumnya.

Cara-cara Mencatatkan Observasi

Ada dua cara pokok tentang mencatatkan observasi itu. 
1. Unit-unit tingkah laku yang akan diamati dirumuskan atau ditentukan lebih dulu, dan catatan-catatan yang dibuat hanyalah mengenai aspek-aspek atau kegiatan yang telah ditentukan.

2. Kita mengadakan observasi tanpa menentukan lebih dulu aspek-aspek atau kegiatankegiatan tingkah laku yang akan diamati. Dengan demikian, menurut cara yang kedua kita dapat memperoleh data yang luas dan bervariasi (banyak macamnya)

Cara yang pertama biasa dilakukan dalam penyelidikan formal (formal studies), sedangkan cara yang kedua baik untuk digunakan bagi situasi-situasi informal. Dalam kegiatan evaluasi proses belajar-mengajar, kedua cara mencatatkan observasi tersebut diatas sering kali diperlukan dan dilakukan oleh guru-guru di sekolah.

kelebihan dan kelemahan observasi

Menurut (Djumhur dan Moh. Surya) selain memiliki kelebihan, observasi juga mempunyai kelemahan - kelemahan, yaitu:

1. Banyak data pribadi yang tidak terungkap, misalnya kehidupan pribadi yang rahasia

2. Memungkinkan terjadi ketidak-wajaran apabila yang diobservasi mengetahui bahwa dirinya sedang diobservasi

3. Observasi banyak tergantung dari faktor yang tidak terkontrol

4. Subjektifitas observer sukar dihindarkan

Upaya-upaya mengatasi kelemahan dalam observasi yaitu :

1. Data-data yang belum terungkap bisa kita resume guna menambah kelengkapan data yang akan kita gunakan. Setelah data-data yang teresume tersebut sudah selesai kita bisa meminta bantuan misalnya dari keluarga, teman-temannya, sahabat dekatnya.

2. Sebagai seorang peneliti harus benar-benar bisa menjaga kerahasiaan dirinya, ini dimungkinkan jika terjadi hal yang tidak diinginkan, misalnya jika identitas observer terbongkar maka pihak yang diteliti merasa tidak nyaman dan akan menghindar dari penelitian yang dilakukan observer yang nantinya akan menghambat proses observasi.

\section{Wawancara}

Wawancara (bahasa Inggris: interview) merupakan percakapan antara dua orang atau lebih dan berlangsung antara narasumber dan pewawancara. Tujuan dari wawancara adalah untuk mendapatkan informasi di mana sang pewawancara melontarkan pertanyaan-pertanyaan untuk dijawab oleh orang yang diwawancarai.

Ankur Garg, seorang psikolog menyatakan bahwa wawancara dapat menjadi alat bantu saat dilakukan oleh pihak yang mempekerjakan seorang calon/ kandidat untuk suatu posisi, jurnalis, atau orang biasa yang sedang mencari tahu tentang kepribadian seseorang ataupun mencari informasi.

Bentuk Wawancara

1. Wawancara berita dilakukan untuk mencari bahan berita. 
2. Wawancara dengan pertanyaan yang disiapkan terlebih dahulu.

3. Wawancara telepon yaitu wawancara yang dilakukan lewat pesawat telepon.

4. Wawancara pribadi.

5. Wawancara dengan banyak orang.

6. Wawancara dadakan / mendesak.

7. Wawancara kelompok dimana serombongan wartawan mewawancarai seorang, pejabat, seniman, olahragawan dan sebagainya.

Sukses tidaknya wawancara selain ditentukan oleh sikap wartawan juga ditentukan oleh perilaku, penampilan, dan sikap wartawan. Sikap yang baik biasanya mengundang simpatik dan akan membuat suasana wawancara akan berlangsung akrab alias komunikatif. Wawancara yang komunikatif dan hidup ikut ditentukan oleh penguasaan permasalahan dan informasi seputar materi topik pembicaraan baik oleh nara sumber maupun wartawan.

\section{Kelebihan teknik wawancara:}

1. Wawancara memberikan kesempatan kepada pewawancara untuk memotivasi orang yang diwawancarai untuk menjawab dengan bebasa dan terbuka terhadap pertanyaa-pertanyaan yang diajukan.

2. Memungkinkan pewawancara untuk mengembangkan pertanyaanpertanyaan sesuai dengan situasi yang berkembang.

3. Pewawancara dapat menilai kebenaran jawaban yang diberikan dari gerak-gerik dan raut wajah orang yang diwawancarai.

4. Pewawancara dapat menanyakan kegiatan-kegiatan khusus yang tidak selalu terjadi.

\section{Kekurangan teknik wawancara:}

1. Proses wawancara membutuhkan waktu yang lama, sehingga secara relatif mahal dibandingkan dengan teknik yang lainnya.

2. Keberhasilan hasil wawancara sangat tergantung dari kepandaian pewawancara untuk melakukan hubungan antar manusia.

3. Wawancara tidak selalu tepat untuk kondisi-kondisi tenpat yang tertentu, misalnya di lokasi-lokasi yang ribut dan rmai.

4. Wawancara sangat menganggu kerja dari orang yang diwawancarai bila waktu yang dimilikinya sangat terbatas.

\section{Kuisioner}

Kuesioner adalah instrumen pengumpulan data atau informasi yang dioperasionalisasikan ke dalam bentuk item atau pertanyaan.Penyusunan kuesioner dilakukan dengan harapan dapat mengetahui variable-variabel apa saja yang menurut responden merupakan hal yang penting . Tujuan penyusunan kuesioner adalah untuk memperbaiki bagian-bagian yang dianggap kurang tepat untuk diterapkan dalam pengambilan data terhadap responden. Yang menjadi dasar pembatasan menentukan variabel-variabel tersebut adalah harus dapat dimengerti dan dirasakan manfaatnya. Kuesioner dapat berfungsi sebagai alat dan sekaligus teknik pengumpulan data yang berisi sederet pertanyaan dalam wujud konkrit. 
Penyusunan kuesioner dilakukan dalam bentuk pertanyaan tertutup. Yang dimaksud dengan pertanyaan tertutup adalah pertanyaan yang membawa responden ke jawaban yangalternatifnya sudah ditetapkan sebelumnya, sehingga responden tinggal memilih pada kolom yang sudah disediakan dengan memberi tanda ' $x$ ' (Arikunto, 1998: 151).

Dalam hal ini, kuesioner untuk konsumen dibagi jadi 2 (dua) bagian, yaitu :

1. Bagian I berisi tentang pertanyaan mengenai data umum responden.

2. Bagian II berisi pertanyaan mengenai kepentingan dan kepuasan pelanggan. Bentuk pertanyaan adalah tertutup dan responden menentukan pilihan jawaban berdasarkan apa yang sudah ditentukan.

Menentukan nilai kepentingan dan kepuasan pelanggan mengenai kualitas jasa pemasaran yang digunakan terdiri dari 5 bagian yaitu 1,2,3,4 dan 5 .

Skala penilaian untuk persepsi adalah :

Bentuk kuesioner lain adalah berisi pertanyaan faktor-faktor peluang dan pertanyaan kritis yang ditujukan kepada karyawan di PT x. Penyebaran kuesioner yang dilakukan sebelumnya melalui uji validasi konstruk untuk mengecek apakah variabel-variabelnya sudah layak atau belum.

Penggunaan kuesioner tepat bila :

1. Responden (orang yang merenpons atau menjawab pertanyaan) saling berjauhan.

2. Melibatkan sejumlah orang di dalam proyek sistem, dan berguna bila mengetahui berapa proporsi suatu kelompok tertentu yang menyetujui atau tidak menyetujui suatu fitur khusu dari sistem yang diajukan.

3. Melakukan studi untuk mengetahui sesuatu dan ingin mencari seluruh pendapat sebelum proyek sistem diberi petunjuk-petunjuk tertentu.

4. Ingin yakin bahwa masalah-masalah dalam sistem yang ada bisa diidentifikasi dan dibicarakan dalam wawancara tindak lanjut.

\section{JENIS PERTANYAAN DALAM KUISONER}

Perbedaaan pertanyaan dalam wawancara dengan pertanyaan dalam kuesioner adalah dalam wawancara memungkinkan adanya interaksi antara pertanyaan dan artinya. Dalam wawancara analis memiliki peluang untuk menyaring suatu pertanyaan, menetapkan istilahistilah yang belum jelas, mengubah arus pertanyaan, memberi respons terhadap pandanmgan yang rumit dan umumnya bisa mengontrol agar sesuai dengan konteksnya. Beberapa diantara peluang-peluang diatas juga dimungkinkan dalam kuesioner. Jadi bagi penganalisis pertanyaan-pertanyaan harus benar-benar jelas, arus pertanyaan masuk akal, pertanyaanpertanyaan dari responden diantisipasi dan susunan pertanyaan direncanakan secara mendetail.

Jenis-jenis pertanyaan dalam kuesioner adalah :

-Pertanyaan Terbuka : pertanyaan-pertanyaan yang memberi pilihan-pilihan respons terbuka kepada responden. Pada pertanyaan terbuka antisipasilah jenis respons yang muncul. Respons yang diterima harus tetap bisa diterjemahkan dengan benar.

-Pertanyaan Tertutup : pertanyaan-pertanyaan yang membatasi atau menutup pilihan-pilihan respons yang tersedia bagi responden. 


\section{BAB IV}

\section{PERHITUNGAN KUISIONER}

\section{DS3 USER(PASIEN)}

\begin{tabular}{|c|c|c|c|c|c|c|c|c|c|c|c|c|c|c|c|c|c|c|}
\hline \multicolumn{19}{|c|}{ REKAP HASIL KUESIONER } \\
\hline \multicolumn{19}{|c|}{ USER } \\
\hline & & & & & & & & & & & & & & PERFOR & RMANCE & EXPEC & CTED & \multirow{3}{*}{ gap } \\
\hline & \multicolumn{4}{|c|}{ PERFORMANCE } & & & & \multicolumn{2}{|c|}{ EXPECTED } & & & & & \multicolumn{4}{|c|}{ MATURITY } & \\
\hline & No & SB & $B$ & $c$ & TB & STB & טגו & SB & $B$ & $C$ & TB & STB & 내 & ACTIVIT & PROSES & ACTIVTY & PROSES & \\
\hline $10 S 3.1$ & 1,1 & & & 4 & 4 & 2 & 10 & 6 & 4 & & & & 10 & 1,47 & \multirow{2}{*}{1,47} & 3,07 & \multirow{2}{*}{2,97} & \multirow[b]{2}{*}{1,50} \\
\hline 2 & 1,2 & & & 4 & 4 & 2 & 10 & 3 & 7 & & & & 10 & 1,47 & & 2,87 & & \\
\hline 3 DS3.2 & 2,1 & & & 3 & 3 & 4 & 10 & 7 & 3 & & & & 10 & 1,27 & \multirow{2}{*}{1,50} & 3,13 & \multirow{2}{*}{3,07} & \multirow[b]{2}{*}{1,57} \\
\hline 4 & 2,2 & & & 7 & 2 & 1 & 10 & 5 & 5 & & & & 10 & 1,73 & & 3,00 & & \\
\hline 5 DS3.3 & 3,1 & & & 3 & 4 & 3 & 10 & 8 & 2 & & & & 10 & 1,33 & \multirow{2}{*}{1,50} & 3,20 & \multirow{2}{*}{3,13} & \multirow[b]{2}{*}{1,63} \\
\hline 6 & 3,2 & & & 6 & 3 & 1 & 10 & 6 & 4 & & & & 10 & 1,67 & & 3,07 & & \\
\hline $70 S 3.4$ & 4,1 & & & 2 & 7 & 1 & 10 & 7 & 3 & & & & 10 & 1,40 & \multirow{2}{*}{1,40} & 3,13 & \multirow{2}{*}{3,10} & \multirow[b]{2}{*}{1,70} \\
\hline 8 & 4,2 & & & 5 & 1 & 4 & 10 & 6 & 4 & & & & 10 & 1,40 & & 3,07 & & \\
\hline
\end{tabular}

DS3 MENAGEMENT

\begin{tabular}{|c|c|c|c|c|c|c|c|c|c|c|c|c|c|c|c|c|c|c|}
\hline & & & & & REKAI & PHASIL & ESIO & & & & & & & & & & & \\
\hline & & & & & & IANAG & & & & & & & & & & & & \\
\hline & & & & & & & & & & & & & & PERFOR & RMANCE & EXPEC & CTED & \\
\hline & & PERFOR & MAN & & & & & EXPECT & & & & & & & MATI & URITY & & gap \\
\hline & No & $S B$ & $B$ & $C$ & TB & STB & 4 & $S B$ & B & c & $\mathrm{TB}$ & STB & & ACTIVITY & PROSES & ACTIVTY & PROSES & \\
\hline 1 DS3.1 & 1,1 & & 3 & & & & 3 & 1 & 2 & & & & 3 & 2,40 & 240 & 2,60 & 280 & \\
\hline 2 & 1,2 & 1 & 1 & 1 & & & 3 & 3 & & & & & 3 & 2,40 & $2,+0$ & 3,00 & 2,00 & 0,40 \\
\hline 3 DS3.2 & 2,1 & & 3 & & & & 3 & 3 & & & & & 3 & 2,40 & 250 & 3,00 & 200 & \\
\hline 4 & 2,2 & 1 & 2 & & & & 3 & 2 & 1 & & & & 3 & 2,60 & 2,30 & 2,80 & 2,90 & 0,40 \\
\hline 5 DS3.3 & 3,1 & & 2 & 1 & & & 3 & 2 & 1 & & & & 3 & 2,20 & 230 & 2,80 & 270 & \\
\hline 6 & 3,2 & & 3 & & & & 3 & 1 & 2 & & & & 3 & 2,40 & 2,30 & 2,60 & 2,10 & 0,40 \\
\hline 7 DS3.4 & 4,1 & 1 & 2 & & & & 3 & 3 & & & & & 3 & 2,60 & 260 & 3,00 & 280 & \\
\hline 8 & 4,2 & 1 & 2 & & & & 3 & 1 & 2 & & & & 3 & 2,60 & 2,00 & 2,60 & 2,80 & 0,20 \\
\hline
\end{tabular}




\section{HASIL DS3}

1.

\begin{tabular}{|l|r|r|r|r|}
\hline & \multicolumn{2}{|c|}{ CURRENT } & \multicolumn{2}{c|}{ Expectacy } \\
\hline & USER & \multicolumn{1}{|c|}{ MGT } & \multicolumn{1}{|c|}{ User } & \multicolumn{1}{|c|}{ MGT } \\
\hline DS3.1 & 1,47 & 2,60 & 2,97 & 2,80 \\
\hline DS3.2 & 1,50 & 3,00 & 3,07 & 2,90 \\
\hline DS3.3 & 1,50 & 2,80 & 3,13 & 2,70 \\
\hline DS3.4 & 1,40 & 3,00 & 3,10 & 2,80 \\
\hline \hline
\end{tabular}

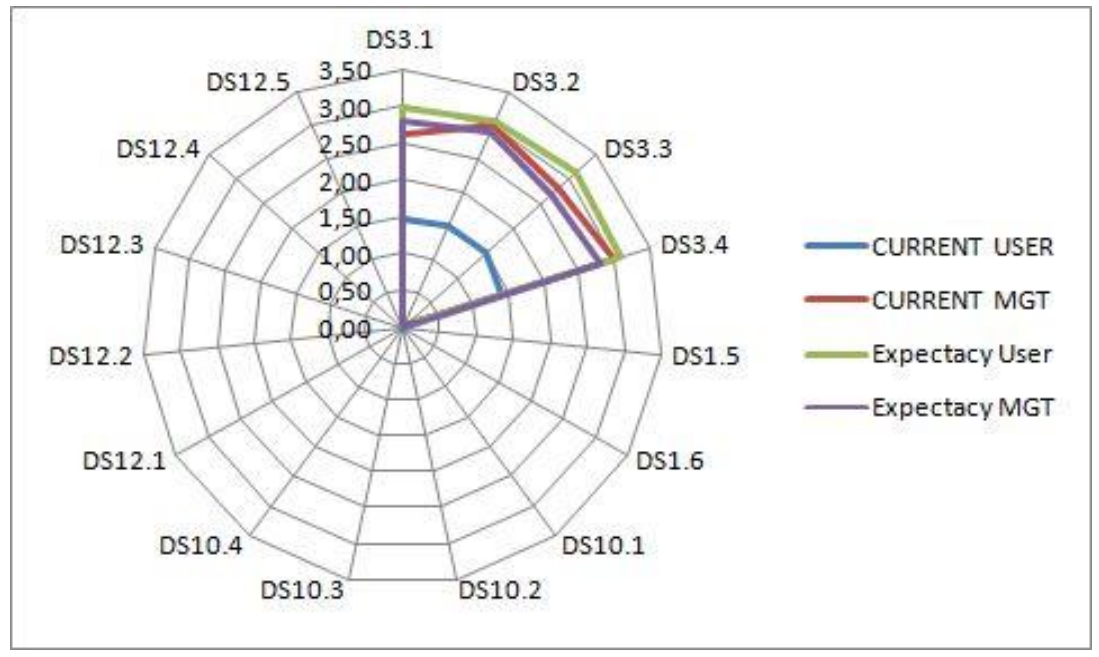

2.

\begin{tabular}{|l|r|r|} 
& $\begin{array}{r}\text { CURRENT } \\
\text { USER }\end{array}$ & $\begin{array}{r}\text { Expectacy } \\
\text { User }\end{array}$ \\
\hline DS3.1 & 1,47 & 3,07 \\
\hline DS3.2 & 1,50 & 3,13 \\
\hline DS3.3 & 1,50 & 3,20 \\
\hline DS3.4 & 1,40 & 3,13 \\
\hline
\end{tabular}

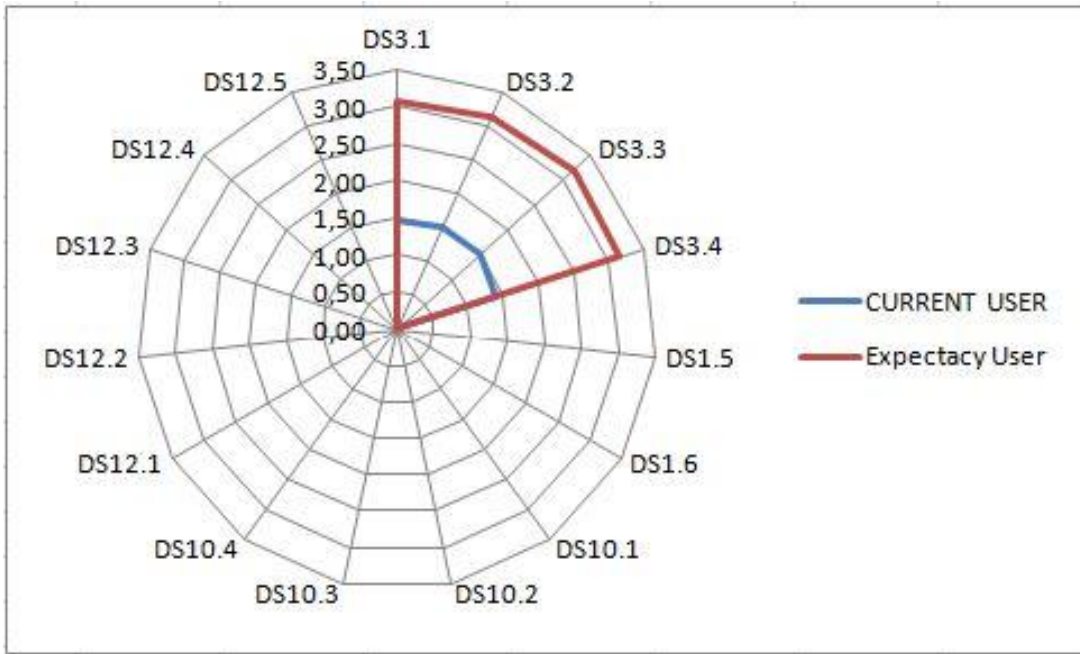




\begin{tabular}{l|r|r|}
\hline & CURRENT & EXPEctacy \\
\hline & MGT & MGT \\
\hline DS3.1 & 2,60 & 2,80 \\
\hline DS3.1 & 3,00 & 2,90 \\
\hline DS3.3 & 2,80 & 2,70 \\
\hline DS3.4 & 3,00 & 2,80 \\
\hline
\end{tabular}

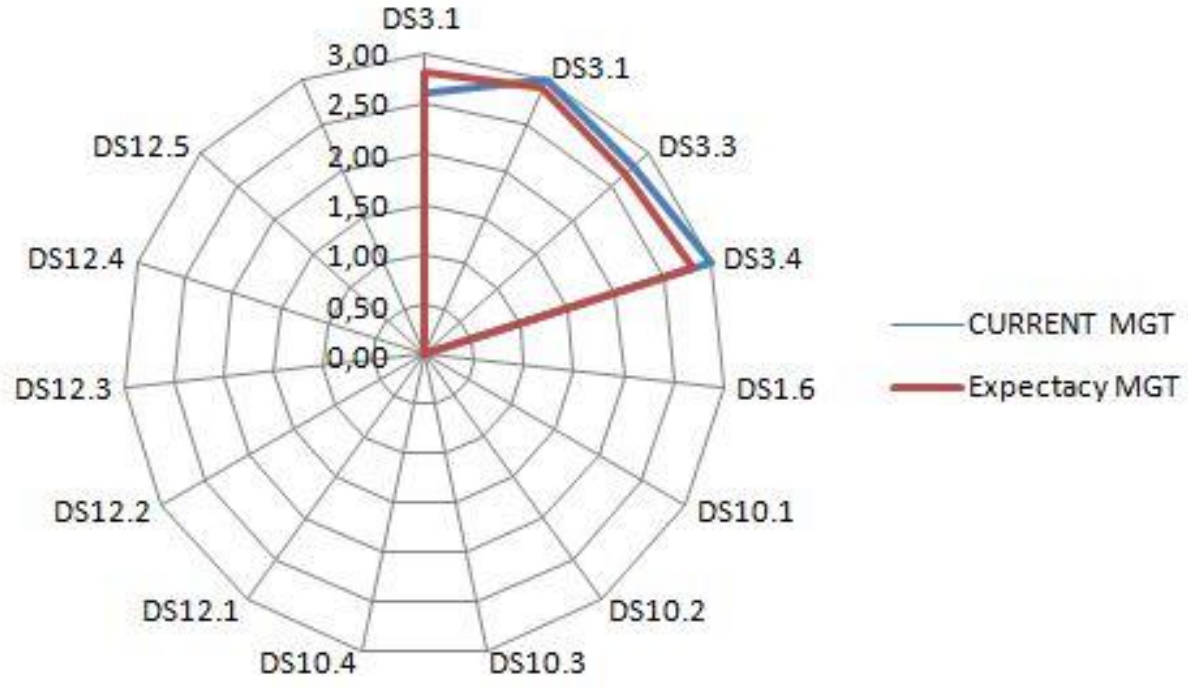

\section{DS8 USER (PASIEN)}

REKAP HASIL KUESIONER

USER

\begin{tabular}{|c|c|c|c|c|c|c|c|c|c|c|c|c|c|c|c|c|c|c|}
\hline & & & & & & & & & & & & & & PERFOR & RMANCE & EXPEC & TED & \multirow{3}{*}{ gap } \\
\hline & \multicolumn{4}{|c|}{ PERFORMANCE } & & & & \multicolumn{2}{|c|}{ EXPECTED } & & & & & \multicolumn{4}{|c|}{ MATURITY } & \\
\hline & No & SB & $B$ & C & TB & STB & I내 & SB & $B$ & C & TB & STB & IUH & ACTVIVT & PROSES & ACTIVITY & PROSES & \\
\hline 1 DS8.1 & 1,1 & & 4 & 1 & 4 & 1 & 10 & 10 & & & & & 10 & 1,87 & \multirow{2}{*}{1,80} & 3,33 & \multirow{2}{*}{3,23} & \multirow[b]{2}{*}{1,43} \\
\hline 2 & 1,2 & & 1 & 4 & 5 & & 10 & 7 & 3 & & & & 10 & 1,73 & & 3,13 & & \\
\hline 3 DS8.2 & 2,1 & & 2 & 4 & 1 & 3 & 10 & 7 & 3 & & & & 10 & 1,67 & \multirow{2}{*}{1,63} & 3,13 & \multirow{2}{*}{3,13} & \multirow[b]{2}{*}{1,50} \\
\hline 4 & 2,2 & & 1 & 3 & 5 & 1 & 10 & 7 & 3 & & & & 10 & 1,60 & & 3,13 & & \\
\hline 5 DS8.3 & 3,1 & & & 4 & 4 & 2 & 10 & 7 & 3 & & & & 10 & 1,47 & \multirow{2}{*}{1,43} & 3,13 & \multirow{2}{*}{3,17} & \multirow[b]{2}{*}{1,73} \\
\hline 6 & 3,2 & & & 3 & 5 & 2 & 10 & 8 & 2 & & & & 10 & 1,40 & & 3,20 & & \\
\hline 7 DS8.4 & 4,1 & & & & 10 & & 10 & 8 & 2 & & & & 10 & 1,33 & \multirow{2}{*}{1,60} & 3,20 & \multirow{2}{*}{3,17} & \multirow[b]{2}{*}{1,57} \\
\hline 8 & 4,2 & & 1 & 6 & 3 & & 10 & 7 & 3 & & & & 10 & 1,87 & & 3,13 & & \\
\hline 9 DS8.5 & 5,1 & & & 2 & 8 & & 10 & 5 & 5 & & & & 10 & 1,47 & \multirow{2}{*}{1,50} & 3,00 & \multirow{2}{*}{3,03} & \multirow[b]{2}{*}{1,53} \\
\hline 10 & 5,2 & & & 4 & 5 & 1 & 10 & 6 & 4 & & & & 10 & 1,53 & & 3,07 & & \\
\hline
\end{tabular}




\section{DS8 MANAGEMENT}

\begin{tabular}{|c|c|c|c|c|c|c|c|c|c|c|c|c|c|c|c|c|c|c|}
\hline \multicolumn{19}{|c|}{ REKAP HASIL KUESIONER } \\
\hline \multicolumn{19}{|c|}{ MANAGEMENT } \\
\hline & & & & & & & & & & & & & & PERFORI & MANCE & EXPEC & CTED & \multirow{3}{*}{ gap } \\
\hline & \multicolumn{4}{|c|}{ PERFORMANCE } & & & \multicolumn{3}{|c|}{ EXPECTED } & & & & & \multicolumn{4}{|c|}{ MATURITY } & \\
\hline & No & SB & B & $\mathrm{C}$ & TB & STB & H & SB & $B$ & $\mathrm{C}$ & TB & STB & H & ACTIVITY & PROSES & ACTIVIT & PROSES & \\
\hline 1 DS8.1 & 1,1 & 1 & 2 & & & & 3 & 2 & 1 & & & & 3 & 2,60 & 2 & 2,80 & 280 & \\
\hline 2 & 1,2 & & 2 & 1 & & & 3 & 2 & 1 & & & & 3 & 2,20 & 2,40 & 2,80 & 2,80 & 0,40 \\
\hline 3 DS8.2 & 2,1 & & 3 & & & & 3 & 2 & 1 & & & & 3 & 2,40 & 230 & 2,80 & 280 & \\
\hline 4 & 2,2 & & 2 & 1 & & & 3 & 2 & 1 & & & & 3 & 2,20 & & 2,80 & & 0,50 \\
\hline 5 DS8.3 & 3,1 & 1 & 2 & & & & 3 & 1 & 2 & & & & 3 & 2,60 & 250 & 2,60 & 270 & \\
\hline 6 & 3,2 & & 3 & & & & 3 & 2 & 1 & & & & 3 & 2,40 & 2,50 & 2,80 & 2,10 & 0,20 \\
\hline 7 DS8.4 & 4,1 & & 3 & & & & 3 & 3 & & & & & 3 & 2,40 & 230 & 3,00 & 290 & \\
\hline 8 & 4,2 & & 2 & 1 & & & 3 & 2 & 1 & & & & 3 & 2,20 & 2,30 & 2,80 & 2,90 & 0,60 \\
\hline 9 DS8.5 & 5,1 & & 2 & 1 & & & 3 & 3 & & & & & 3 & 2,20 & 20 & 3,00 & 280 & \\
\hline 10 & 5,2 & & 2 & 1 & & & 3 & 1 & 2 & & & & 3 & 2,20 & 2,20 & 2,60 & 2,00 & 0,60 \\
\hline
\end{tabular}

\section{HASIL DS8}

1.

\begin{tabular}{|l|r|r|r|r|}
\hline & \multicolumn{2}{|c|}{ CURRENT } & \multicolumn{2}{c|}{ Expectacy } \\
\hline & USER & \multicolumn{1}{|c|}{ MGT } & \multicolumn{1}{c|}{ User } & \multicolumn{1}{c|}{ MGT } \\
\hline DS8.1 & 1,80 & 2,80 & 3,23 & 2,80 \\
\hline DS8.2 & 1,63 & 2,80 & 3,13 & 2,80 \\
\hline DS8.3 & 1,43 & 2,60 & 3,17 & 2,70 \\
\hline DS8.4 & 1,60 & 3,00 & 3,17 & 2,90 \\
\hline DS8.5 & 1,50 & 3,00 & 3,03 & 2,80 \\
\hline
\end{tabular}

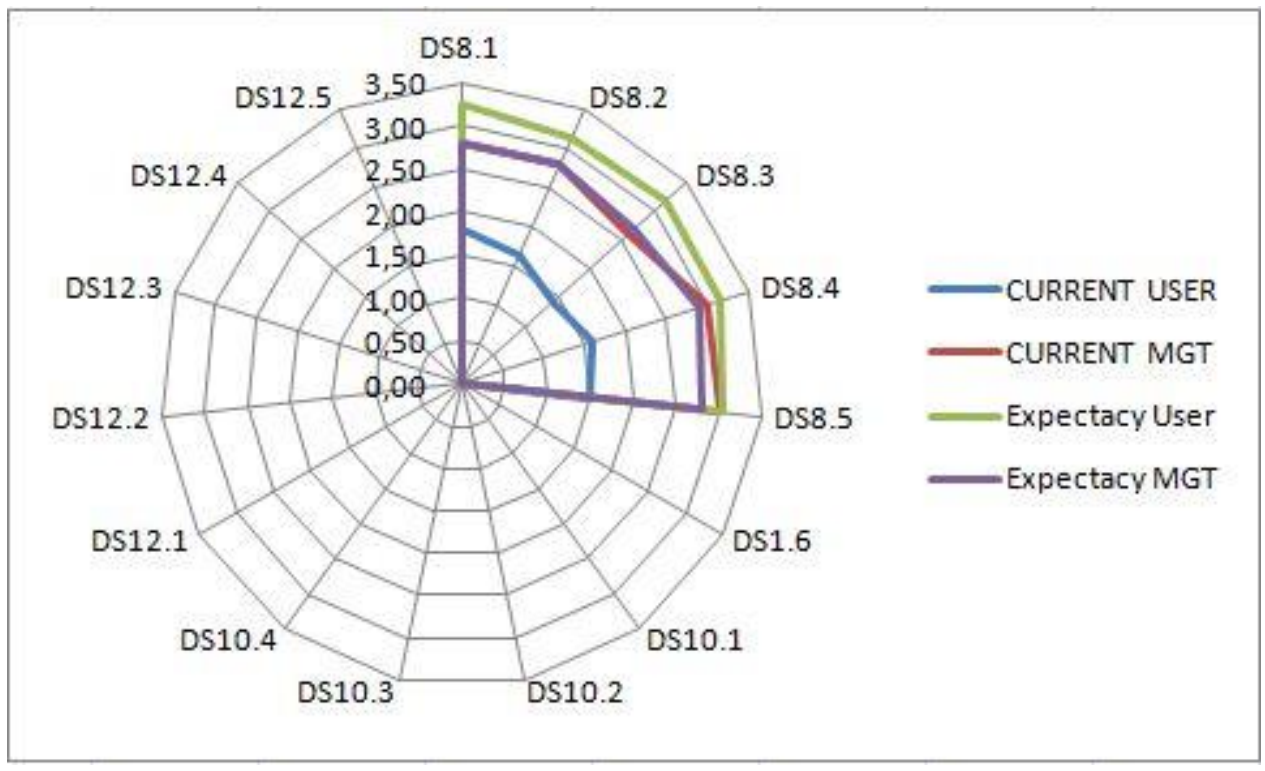


2.

\begin{tabular}{|l|r|r|}
\hline & $\begin{array}{c}\text { CURRENT } \\
\text { USER }\end{array}$ & $\begin{array}{c}\text { EXpectacy } \\
\text { User }\end{array}$ \\
\hline DS8.1 & 1,80 & 3,33 \\
\hline DS8.2 & 1,63 & 3,13 \\
\hline DS8.3 & 1,43 & 3,13 \\
\hline DS8.4 & 1,60 & 3,20 \\
\hline DS8.5 & 1,50 & 3,00 \\
\hline
\end{tabular}

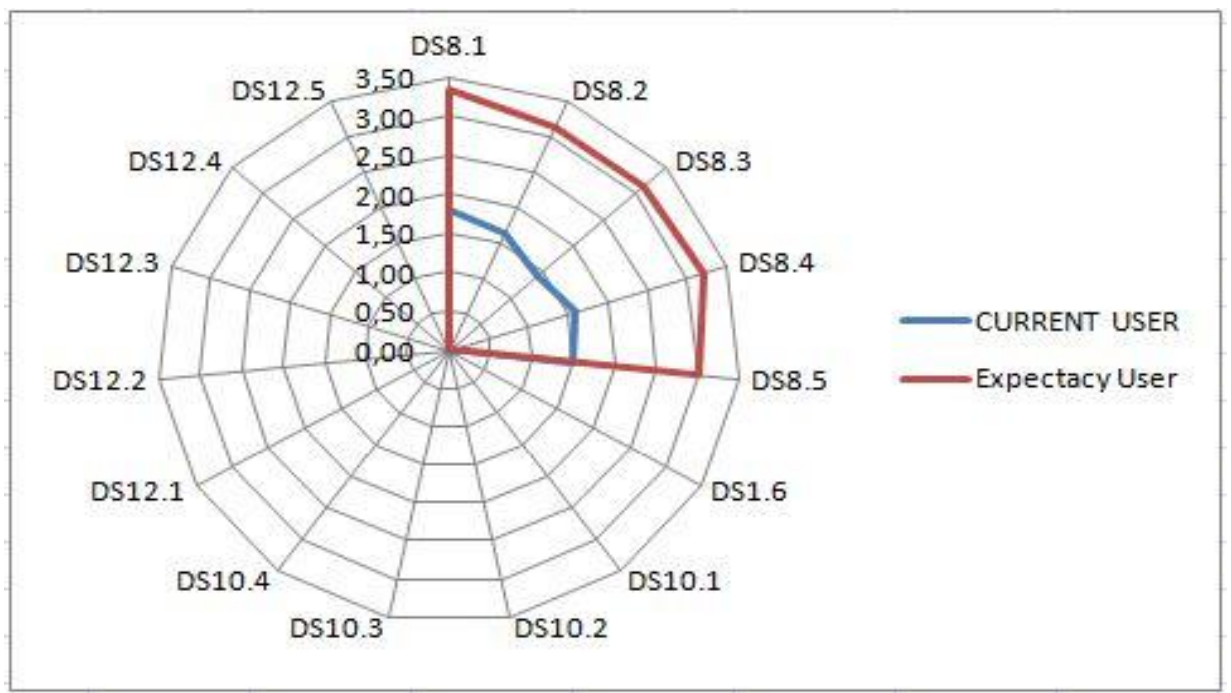

3.

\begin{tabular}{|l|r|r|}
\hline & CURRENT & EXpectacy \\
\hline & MGT & MGT \\
\hline DS8.1 & 2,80 & 2,80 \\
\hline DS8.2 & 2,80 & 2,80 \\
\hline DS8.3 & 2,60 & 2,70 \\
\hline DS8.4 & 3,00 & 2,90 \\
\hline DS8.5 & 3,00 & 2,80 \\
\hline
\end{tabular}

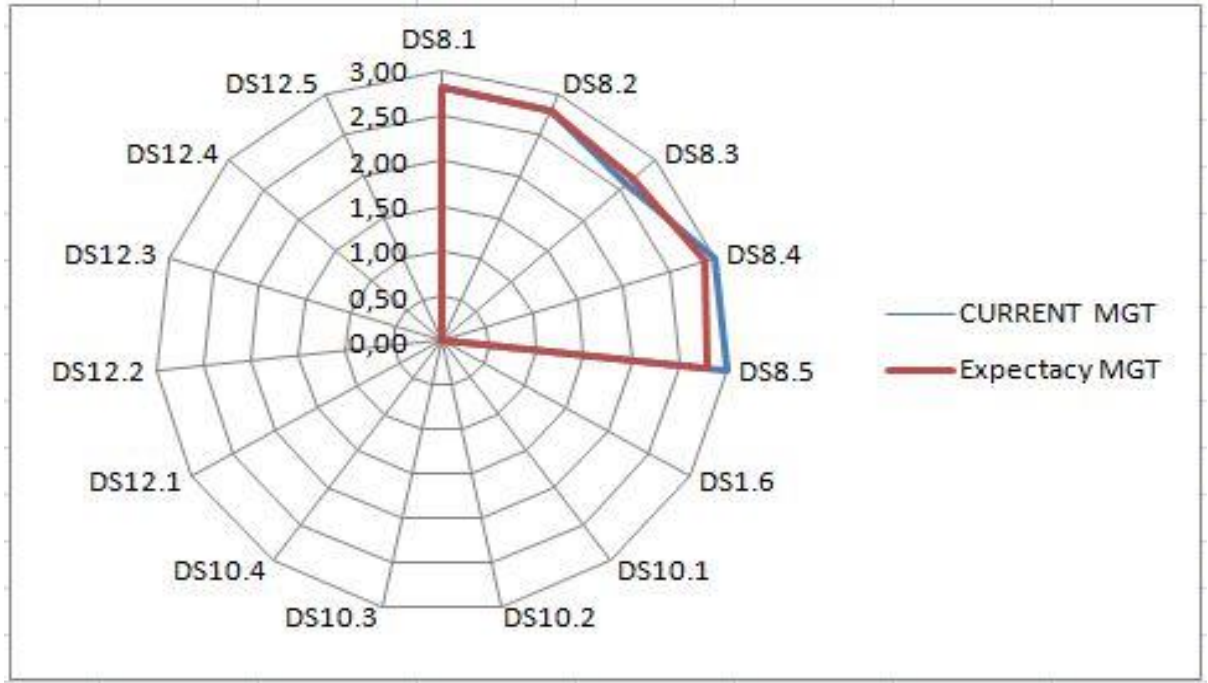




\section{BAB V}

\section{PENUTUP}

\subsection{Kesimpulan}

Dari penulisan proposal ini dapat disimpulkan bahwa Audit Sistem Informasi adalah proses pengumpulan dan pengevaluasian bukti-bukti untuk membuktikan dan menentukan apakah sistem aplikasi komputerisasi yang digunakan telah menetapkan dan menerapkan sistem pengendalian intern yang memadai, apakah aset organisasi sudah dilindungi dengan baik dan tidak disalah gunakan, apakah mampu menjaga integritas data, kehandalan serta efektifitas dan efisiensi penyelenggaraan sistem informasi berbasis komputer.

Konteks dalam proses audit sistem informasi ini terbagi menjadi 3 yaitu audit sistem informasi berbasis risiko, audit sistem informasi berbasis kendali, audit sistem informasi berbasis komputer.

\subsection{Kritik dan Saran}

Penulis hanya bisa memberi saran kepada pembaca bahwasahnya konsep audit sistem informasi yaitu terdiri dari tujuan audit sampai dengan proses audit sistem informasi itu sendiri baik itu berbasis risiko, berbasis kendali serta berbasis komputer.

Di dalam proposal ini mungkin masih banyak suatu kekurangan dan kesalahan oleh karena itu saya pun meminta agar kiranya pembaca juga memberikan keritikan dan sarannya agar kiranya proposal ini bisa menjadi lebih sempurna lagi. 


\section{LAMPIRAN DOKUMENTASI}
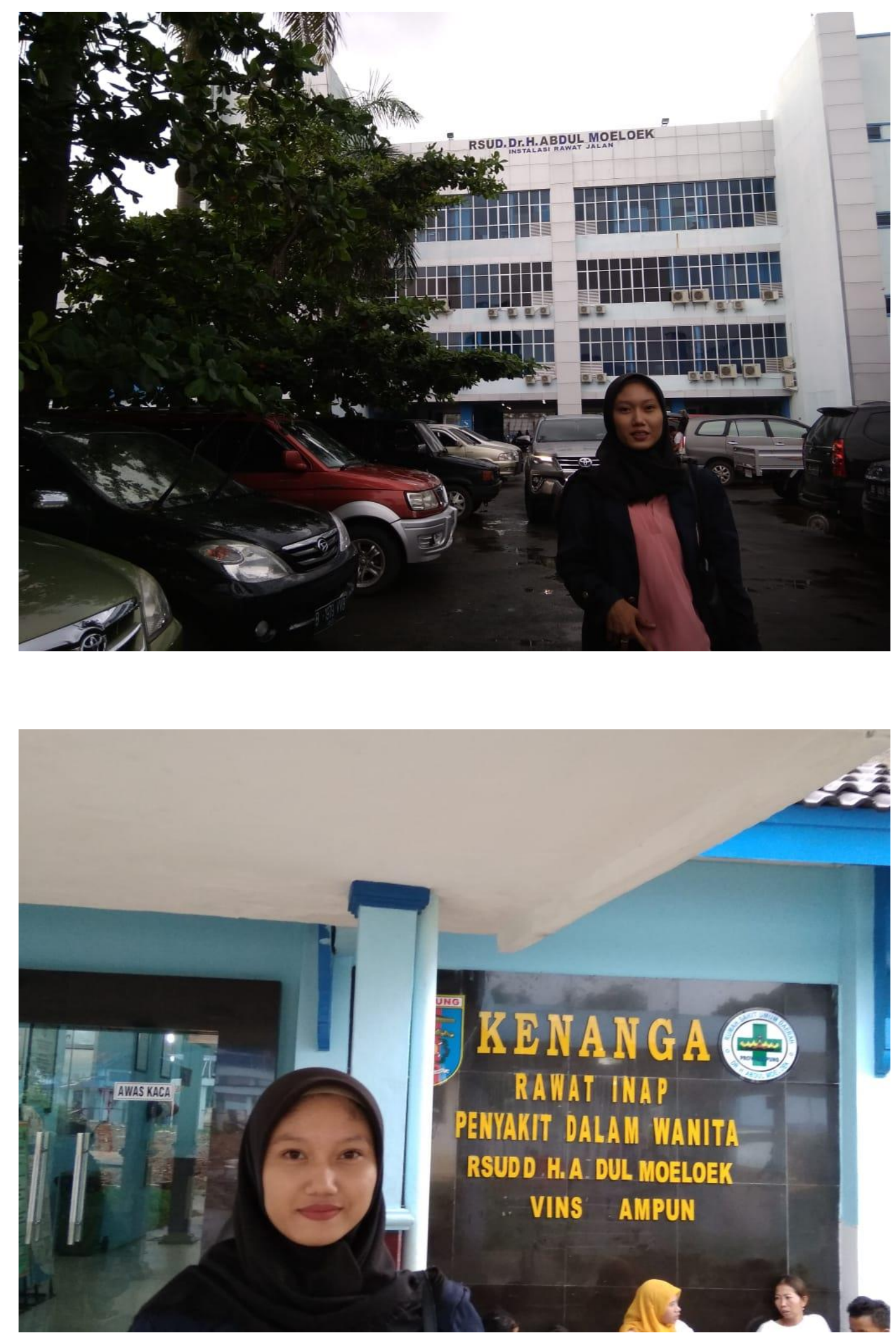


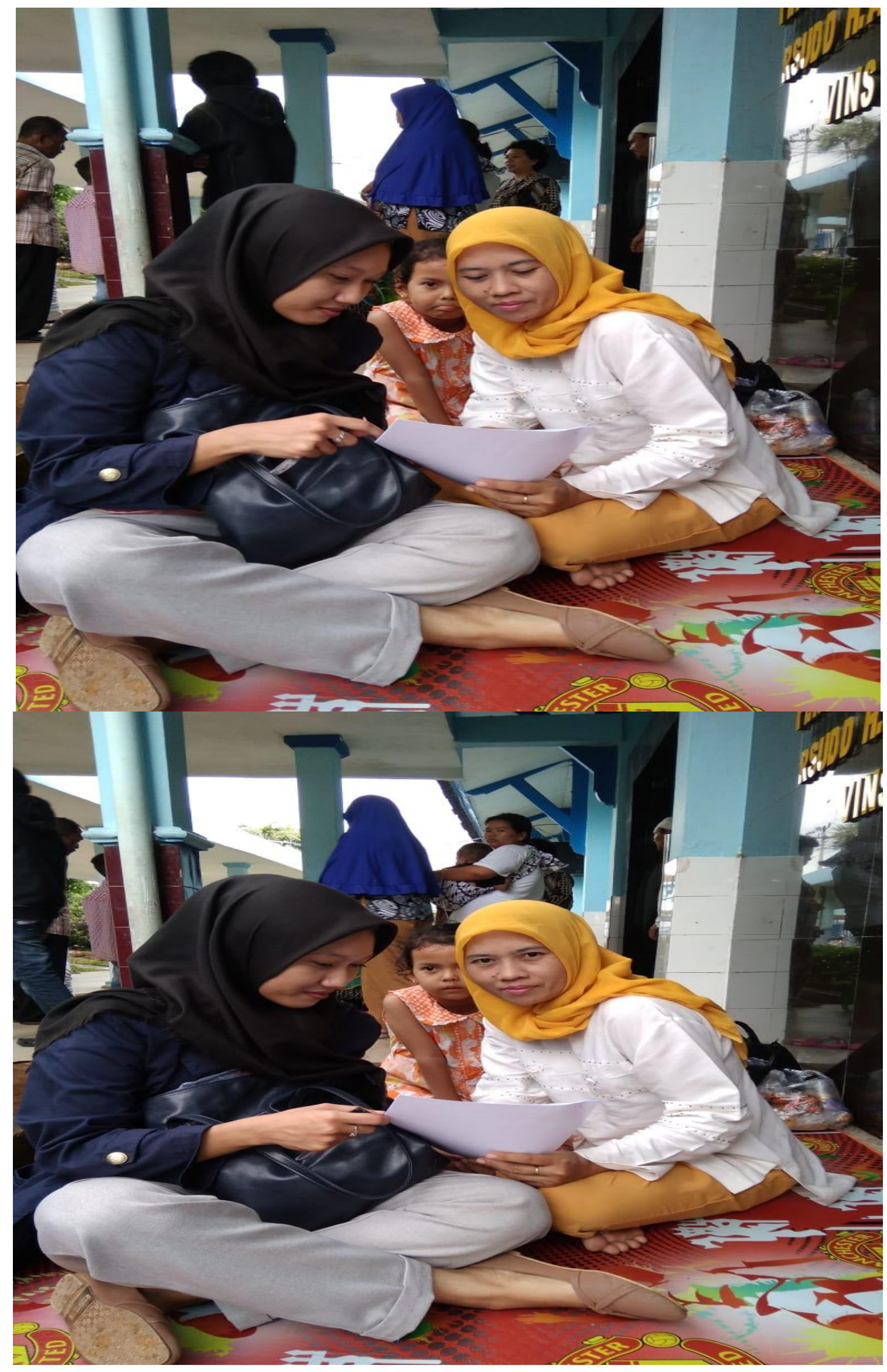




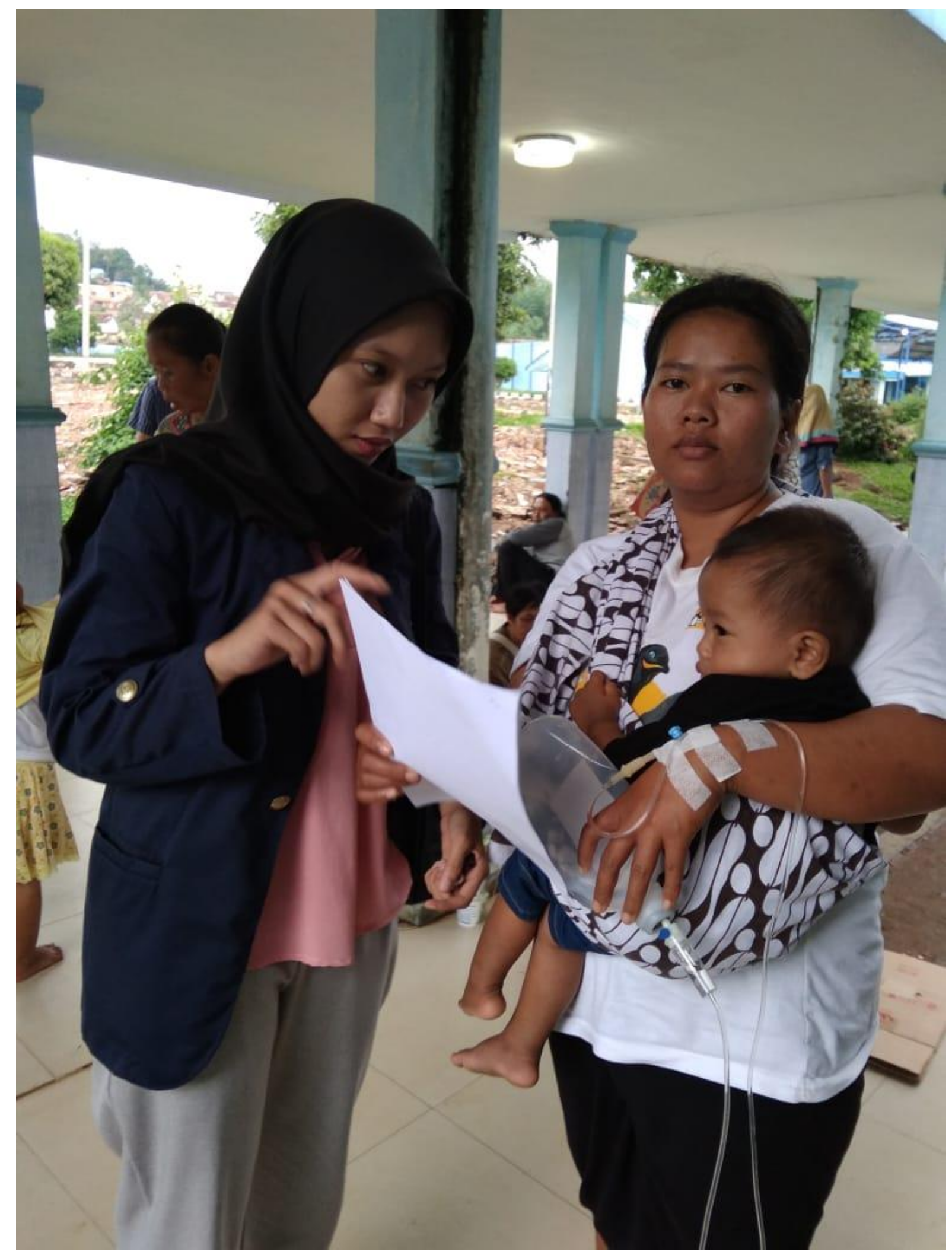



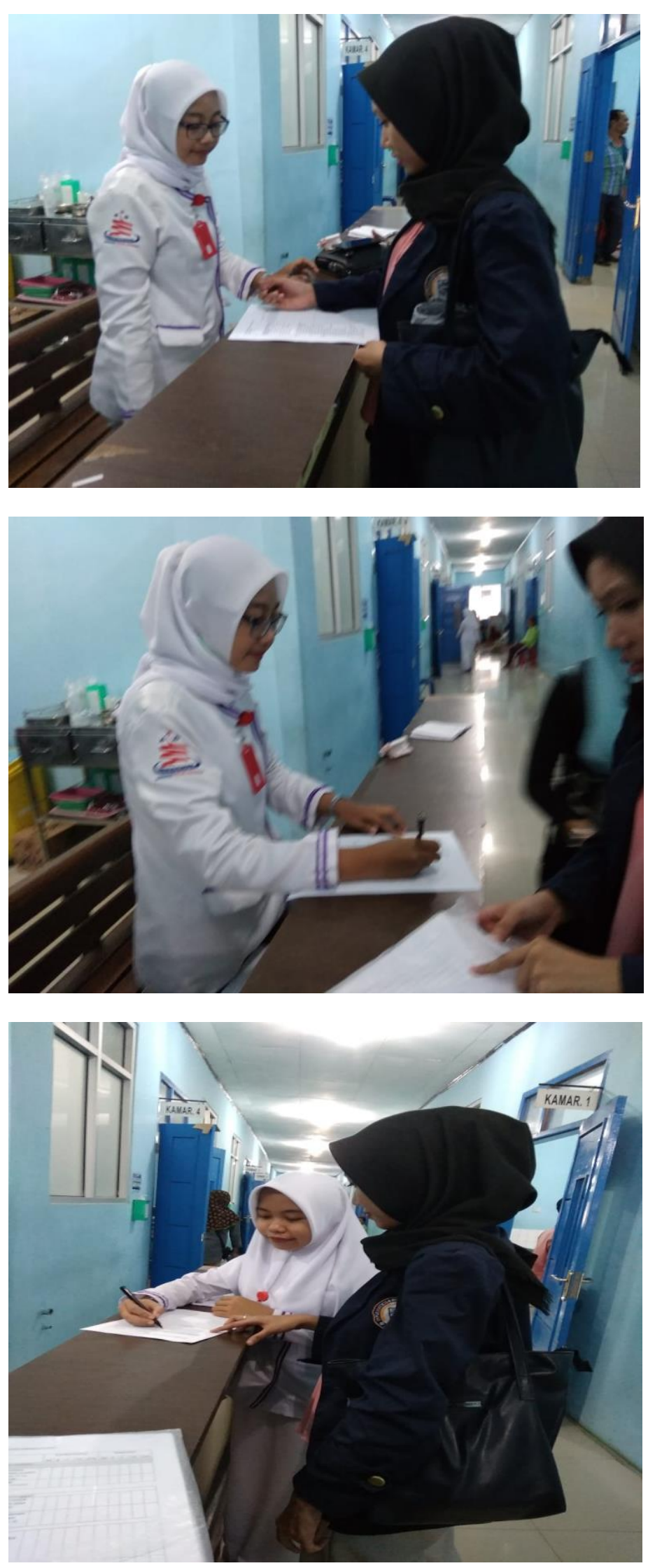
